\title{
Life cycle assessment and eco-efficiency Indicator for ulos weaving using loom machine in Toba Samosir Regency of North Sumatra
}

\author{
Yuli Yanthi Siagian ${ }^{1, *}$, Rizal Sinaga ${ }^{1}$, Christoper Sinaga ${ }^{1}$, and Yosef Manik ${ }^{1}$ \\ ${ }^{1}$ Institut Teknologi Del, Engineering Management Study Program, Laguboti, 22381, Indonesia
}

\begin{abstract}
Toba Samosir Regency is one of the centers of ulos weaving in North Sumatera. Most of the weaving processes are carried out traditionally by small-size enterprises. However, it is identified that there are 8 ulos weaving industries that utilize loom machine. To date, no holistic environmental impact assessment has yet been conducted on weaving industry in Toba Samosir. This study aims to assess potential environmental impact caused by weaving industry in Toba Samosir. The scope of this study covers gate-to-gate stages in ulos production, consisting mangiran, washing, dipping, drying, dying, boiling, sun-drying, weaving, and manirat. The functional unit of this study is $182 \mathrm{~kg}$ of ulos, representing one batch of production. The assessments are conducted by two approaches; these are Life Cycle Assessment and Eco-efficiency Index measurement. The LCA modeling and computation of environmental impacts are aided by openLCA software. From LCA, it is revealed that the potential environmental impacts associated with ulos weaving are Eutrophication Potential $(5.28 \mathrm{E}+01 \mathrm{~kg} \mathrm{PO} 4 \mathrm{eq}-8.41 \mathrm{E}+01 \mathrm{~kg} \mathrm{PO} 4 \mathrm{eq})$, Climate Change Potential (7.17E $+02 \mathrm{~kg} \mathrm{CO} 2 \mathrm{eq}-5.74 \mathrm{E}+02 \mathrm{~kg} \mathrm{CO} 2 \mathrm{eq})$, and Photochemical Oxidation Potential $(3.40 \mathrm{E}+00 \mathrm{~kg}$ CFC-11 eq $4.68 \mathrm{E}+01 \mathrm{~kg}$ CFC-11 eq). The major stressors causing these impacts are using firewood. The calculation result of Eco-Efficiency Index (EEI) for weaving industry in Toba Samosir Regency falls between 0,1 and 0,4 , which indicates the product is affordable but not sustainable..
\end{abstract}

\section{Introduction}

Eco-efficiency concept was firstly introduced by World Business Council for Sustainable Development (WBCSD) in 1992. Along with the higher level of public awareness in developing the industry by considering environmental sustainability aspects, the ecoefficiency concept is very appropriate if it can be practiced in the industrial world. The research related to eco-efficiency is still largely focused on big industries, not many have touched the Small and Medium Industries (SMI).

The process of making ulos cannot be separated from the use of chemicals, especially in the yarn coloring process using synthetic dyes. The use of chemical dyes will produce

\footnotetext{
${ }^{*}$ Corresponding author: yuliyanthisiagian@gmail.com
} 
waste that can potentially have a negative impact on the environment and human health if no processing is carried out to reduce the impact of the waste. Meanwhile there has not been yet measurement and research that measures the impact on the production process of ulos.

To increase eco-efficiency production and minimize waste generated in the ulos industrial process, it is recommended that sustainable production by generating competitive products that are environmentally friendly towards eco-efficiency is applied as best as possible. To find out the sustainable level of a product, it is necessary to measure the ecoefficiency level of ulos products. Eco-efficiency measurement can be conducted using the Life Cycle Assessment (LCA) method. The LCA method analysis will show the parts of raw materials or processes that have the most potential for the environmental impact. Based on the LCA analysis, improvements can be proposed to improve product quality.

This study aims to assess the environmental impact of the entire production process of ulos weaving produced by the machine looms. This research needs to be conducted to make decisions in creating environmentally friendly production processes and sustainable production. This research is also supported through the results of laboratory tests to determine the liquid waste content of the ulos weaving production process.

\section{Methods}

\subsection{Data processing structure}

Data was obtained through an interview process with ulos weaving owners and from other sources. General data from the ulos SMI in Toba Samosir can be seen in Table 1.

The tools used in measuring the efficiency of Ulos products include Life Cycle Assessment, Eco Cost, Net Value. The final calculation of this method is Eco-efficiency Ratio. In the LCA calculation, openLCA software will be used. For more details, the data processing structure is shown in Figure 1.

\subsubsection{Eco-efficiency and Life Cycle Assessment (LCA)}

Eco-efficiency concept was firstly introduced by World Business Council for Sustainable Development (WBCSD) in 1992. This concept is directed to ensure sustainable development. Eco-efficiency guarantees sustainable production because the use of natural resources and waste management can be controlled. The definition of eco-efficiency according to WBCSD is a concept that based on the achievement of a quality life which is determined through price competition of goods and services to provide satisfaction. This satisfaction is obtained by reducing the environmental impact and reducing the use of resources during the life cycle [1]. Another understanding of eco-efficiency is the relationship between the concepts of efficient use of natural resources, water, energy, and the concept of economic efficiency by taking into environmental impacts that occurred [2].

At the LCA stage, measurement of the potential impacts resulting from the ulos weaving process is carried out. The calculation of LCA is divided into three phases, those are [3]: (1) LCA goal and scope. This phase aims to formulate and describe the objectives, the system to be evaluated, and the constraints related to impacts throughout the life cycle of the ulos weaving system. (2) Life Cycle Inventory (LCI) shows the material needs and energy requirements used during the process to produce ulos weaving. (3) Life Cycle Impact Assessment (LCIA) is an analysis phase of type and magnitude of impact categories produced. This process is conducted using openLCA software with the 2005 CML Baseline 
method. Through the category of impact produced, the value of eco-cost will be obtained from ulos weaving products.

Table 1. Types of data input.

\begin{tabular}{|c|c|c|c|}
\hline Method & Input data & Output & $\begin{array}{l}\text { Data } \\
\text { collection } \\
\text { technique }\end{array}$ \\
\hline LCA & $\begin{array}{l}\text { Material: Naphthol dyes (kg), Salt (kg), } \\
\text { Teepol (kg), Water (liter), Firewood (kg) } \\
\text { Energy: Electricity (kWh) } \\
\text { Waste: Liquid Waste (liter) }\end{array}$ & $\begin{array}{l}\text { The magnitude of the } \\
\text { impact resulting from the } \\
\text { production process }(\mathrm{kg} \\
\text { impact eq) }\end{array}$ & Interview \\
\hline $\begin{array}{l}\text { Eco- } \\
\text { Cost }\end{array}$ & $\begin{array}{l}\text { The magnitude of the impact generated } \\
\text { from the LCA (kg impact eq) }\end{array}$ & $\begin{array}{l}\text { Impact prevention costs } \\
\text { (Rupiah) }\end{array}$ & $\begin{array}{l}\text { Literature } \\
\text { Study }\end{array}$ \\
\hline $\begin{array}{l}\text { Net } \\
\text { Value }\end{array}$ & $\begin{array}{l}\text { Material costs, energy costs, labor costs, } \\
\text { maintenance costs, and selling prices } \\
\text { (Rupiah) }\end{array}$ & Net value product (Rupiah) & Interview \\
\hline EEI & Net value and eco-cost & $\begin{array}{l}\text { Aaffordable and sustainable } \\
\text { or not }\end{array}$ & $\begin{array}{l}\text { Literature } \\
\text { Study }\end{array}$ \\
\hline EVR & Net value and eco-cost & EVR percentage rate ratio & $\begin{array}{l}\text { Literature } \\
\text { Study }\end{array}$ \\
\hline EER & EVR & Eco-efficiency rate & $\begin{array}{l}\text { Literature } \\
\text { Study }\end{array}$ \\
\hline
\end{tabular}

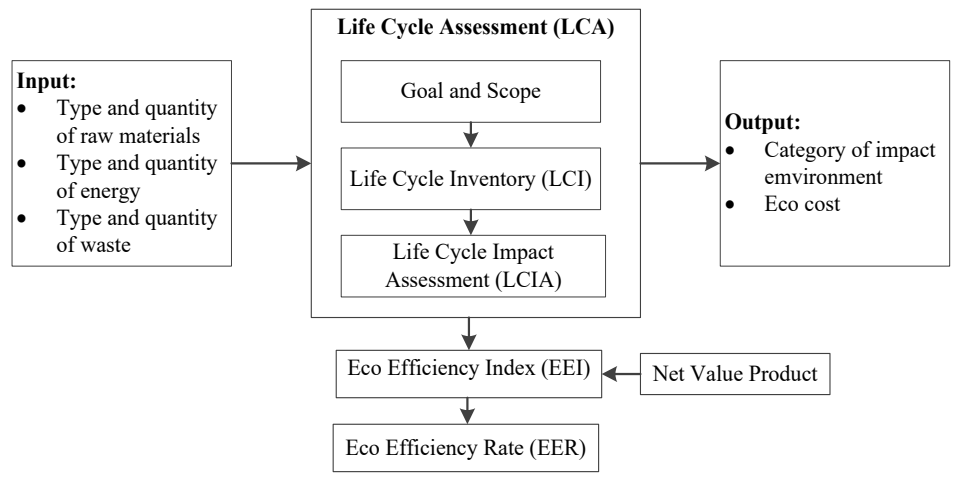

Fig. 1. Data processing structure.

\subsubsection{Net Value}

Net value is obtained by reducing the selling price of products with production costs obtained based on the cost of the process [4]. Thus the profit of a company can be measured using a net value in equation (1)[4]. The input net value includes costs related to the production process of ulos products such as raw material costs, energy costs, labour costs, maintenance costs, and product selling prices.

$$
\text { Net Value }=\text { Selling price-Production Cost }
$$

\subsubsection{Eco-Efficiency Index (EEI) product and Eco-Efficiency Ratio (EER)}

EEI calculation aims to find out the affordable and sustainable value of ulos weaving production. EEI input in the form of eco-cost generated and net value of the product. EEI calculations can be seen in the equation (2)[5]. 


$$
\mathrm{EEI}=\frac{\text { price }-\cos t}{\cos t+E \operatorname{cocost}}
$$

Products are affordable and sustain if the EEI value $>1$. Meanwhile, the products are affordable but not sustain if the EEI between 0 and 1 . Products are not affordable and do not sustain if the EEI value $<0$.

Eco-Efficiency Ratio (EER) calculation starts through the calculation phase of the Ecocosts per value ratio (EVR) of the product. The calculation of EVR is obtained by dividing the eco-cost value generated by net value. EVR rate calculation can be seen in the equation (3)[6].

$$
\mathrm{EVR}=\frac{e c o \text { cost }}{\text { net value }}
$$

To obtain the EER value for ulos weaving products, the EVR value that has been obtained will be deducted by 1 and multiplied by $100 \%$. EER rate calculation is shown in equation (4) [1].

$$
E E R=(1-E V R) \times 100 \%
$$

\section{Results and discussion}

\subsection{Life Cycle Assessment (LCA)}

Laboratory testing is conducted by taking waste samples from 3 ulos weaving factories which is shown in table 2. The parameters measured in this laboratory test are the value of Chemical Oxygen Demand (COD) and Biological Oxygen Demand (BOD). The test results will be compared with the quality standards of wastewater activities in the textile industry by the Environmental Ministry. The following are the results of the testing of wastewater from each weaving factory.

Based on the results of laboratory tests on BOD5 and COD, the waste produced from each ulos plant exceeds the National quality standard. Based on these results, the SMI wastewater weaving ulos in Toba Samosir has exceeded the maximum permissible levels, so that it is not good for the environment.

The scope of this research is gate-to-gate which covers all activities and material output involved in the production process of ulos weaving. The functional unit is defined as the production of $182.6 \mathrm{~kg}$ ulos, representing one batch of production. Based on calculations, it was found that the environmental impact caused by the production process of ulos weaving was the category of climate change, eutrophication, and photochemical oxidation impacts.

a. Climate Change

Table 3 shows the Climate Change Impact. The most dominant production process in PT 1, PT 2, and PT 5 causes climate change is steaming process that uses large amounts of firewood. Besides that, it is caused by the dyeing process that uses synthetic dyes. Liquid waste containing synthetic dyes and other chemicals contains high COD, which results in high methane gas. Meanwhile, PT 8 did not do the dyeing process. So that the production process of PT 8 which gives the most impact is the process of agreement that uses large amounts of fuel wood.

b. Eutrophication

Based on table 4, the biggest contributor to eutrophication is the process of dyeing and steaming at PT 1, PT2, and PT 5. Meanwhile, the production process of PT 8 has the most impact on the starching process. The three processes use large amounts of fuel wood. 
Burning of firewood which produces exhaust gas in the form of N2 has an impact on eutrophication.

c. Photochemical oxidation

Table 5 shows Photochemical Oxidation. The contributors to the photochemical oxidation effects of the entire process were obtained from dyeing, starching, and steaming. In this process there is a burning of firewood that produces $\mathrm{CO}$ exhaust which has a large impact on photochemical oxidation.

Table 3. Laboratory test result of liquid waste.

\begin{tabular}{|c|c|c|c|c|}
\hline \multirow[t]{2}{*}{$\begin{array}{c}\text { Parameter } \\
(\mathrm{mg} / \mathrm{L})\end{array}$} & \multirow{2}{*}{$\begin{array}{c}\text { Maximum } \\
\text { Level } \\
(\mathrm{mg} / \mathrm{L}) \\
\end{array}$} & \multicolumn{3}{|c|}{$\begin{array}{c}\text { Test Result } \\
(\mathrm{mg} / \mathrm{L})\end{array}$} \\
\hline & & PT 1 & PT 2 & PT 5 \\
\hline COD & 150 & 863 & 910 & 880 \\
\hline $\mathrm{BOD}_{5}$ & 60 & 357 & 446 & 334 \\
\hline
\end{tabular}

Table 2. Climate change impact.

\subsection{Eco-efficiency}

\subsubsection{Eco cost and Net Value}

Eco-cost calculations have been carried out in the European Union which is an indication of the prevention of marginal costs. This prevention cost is issued by the WBCSD for emissions of toxic substances as implemented in the 2017 eco-costs system. The cost of preventing environmental impacts in euros will be converted to rupiah units. Rupiah conversion is adjusted to the exchange rate that applies in May 2018 from Bank Indonesia data. The eco-cost value of each weaving plant is shown in Table 6 .

Net value of the product is a comparison of economic factors to the environment in the form of eco cost value from each Weaving Factory. The net value for each factory is shown in Table 7.

\subsubsection{Eco-efficiency Index (EEI) and Eco-Costs per Value Ratio (EVR)}

Figure 2 shows a comparison of EEI values in the four weaving factories in Toba Samosir. It shows that ulos weaving in Toba Samosir belongs to the unsustainable but affordable category because the EEI value of the ulos weaving is between $0-1$. This condition shows that batik chemical dyes are less environmentally friendly but financially The figure also shows that the EEI Weaving 2 value is higher than the others. This is because the value of the factory ulos selling price is higher than that of other factories, which is Rp. 120,000 / sheet. Therefore, a higher selling price can get more profit to cover eco-cost. Meanwhile, the Weaving 8 factory sells ulos at a price of $\mathrm{Rp} \mathrm{100,000/sheet,} \mathrm{which} \mathrm{is} \mathrm{not} \mathrm{much}$ different from the Weaving Factory 2.

Figure 2 also shows the value of EEI Weaving Factory 8 is lower than other factories. This is because the factory does not do the dyeing process, but buys the dyed yarn. The price of colored yarn is more expensive than the yarn that has not been colored. So that the EEI value of weaving factory 8 will be lower because of the high price of raw materials.

Eco-Costs perValue Ratio (EVR) is obtained by dividing eco-costs with net value as the economic value of each factory. The EVR value is shown in Table 8 . Through table 8 , it can be seen that EVR weaving of PT 1, PT 2, PT, 5, and PT 8 are respectively $0.6,0.4,0.8$, and 0.9. The greater the net value, the smaller the EVR value. The smaller the EVR value, the better and more worthy of the product to produce. This is inversely proportional to the EEI value that has been previously calculated. The greater the EVR value, the smaller the 
EEI value, and vice versa if EEI gets bigger, the EVR value gets smaller. This EVR calculation is used as input at the stage of determining the eco-efficiency level of ulos weaving products

Table 5. Eutrophication impact.

\begin{tabular}{|l|l|}
\hline Plant & Total(kg PO4- eq.) \\
\hline PT 1 & 84.14 \\
\hline PT 2 & 78.44 \\
\hline PT 5 & 68.44 \\
\hline PT 8 & 52.76 \\
\hline
\end{tabular}

Table 4. Photochemical oxidation.

\begin{tabular}{|c|c|}
\hline Plant & Total (kg 1,4-dichlorobenzene eq.) \\
\hline PT 1 & 46.77 \\
\hline PT 2 & 4.74 \\
\hline Plant & Total (kg 1,4-dichlorobenzene eq.) \\
\hline PT 5 & 3.43 \\
\hline
\end{tabular}

Table 6. Eco cost.

\begin{tabular}{|c|c|c|c|c|}
\hline \multirow[t]{2}{*}{ Impact Category } & \multicolumn{4}{|c|}{ Eco Cost } \\
\hline & PT 1 & PT 2 & PT 5 & PT 8 \\
\hline Climate change & $\operatorname{Rp} 1.383 .438$ & Rp 1.108.316 & Rp 1.102.676 & $\begin{array}{ll}\mathrm{Rp} & 882.209\end{array}$ \\
\hline Eutrophication & Rp 5.835.936 & Rp 5.440 .046 & RP 4.746 .486 & $\operatorname{Rp} 3.659 .081$ \\
\hline Photochemical oxidation & Rp 412.275 & 41.799 & $\mathrm{Rp} \quad 30.195$ & Rp 29.971 \\
\hline Total & Rp 7.631.650 & Rp 6.590 .161 & Rp 5.874.882 & Rp 4.571.261 \\
\hline
\end{tabular}

Table 7. Net value.

\begin{tabular}{|c|c|c|c|c|}
\hline \multirow{2}{*}{ Remarks } & \multicolumn{4}{|c|}{ Value (Rp) } \\
\cline { 2 - 5 } & PT 1 & PT 2 & PT 5 & PT 8 \\
\hline Price/ 1 bal Ulos & $\mathrm{Rp} \mathrm{43.200.000}$ & $\mathrm{Rp} \mathrm{45.000.000}$ & $\mathrm{Rp} \mathrm{30.600.000}$ & $\mathrm{Rp} \mathrm{36.000.000}$ \\
\hline Production Cost/ 1 bal Ulos & $\mathrm{Rp} \mathrm{30.254.865}$ & $\mathrm{Rp} \mathrm{29.990.828}$ & $\mathrm{Rp} 23.663 .753$ & $\mathrm{Rp} \mathrm{31.190.432}$ \\
\hline Product Net Value / 1 bal Ulos & $\mathrm{Rp} 12.945 .135$ & $\mathrm{Rp} 15.009 .172$ & $\mathrm{Rp} 6.936 .247$ & $\mathrm{Rp} 4.809 .568$ \\
\hline
\end{tabular}

\subsection{Eco-efficiency Rate (EER)}

The final EER value shows the eco-efficiency level of the ulos product. Eco-efficiency values will be smaller if the eco-costs value is higher and the net value is lower. So that the eco-efficiency of a product will be judged worse. Conversely, if the lower the value of ecocosts and the higher the net value, then it can be said that the eco-efficiency value of the product will be better.

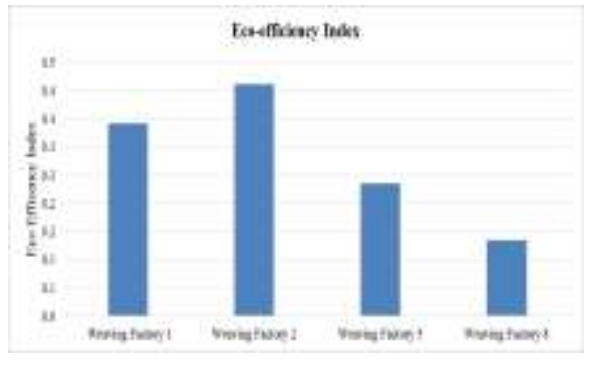

Fig. 2. Eco-efficiency of weaving ulos.

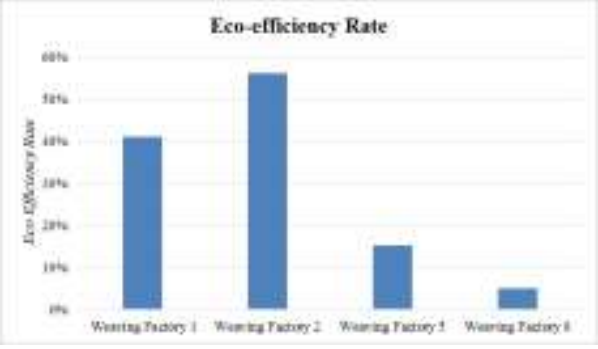

Fig. 3. Eco-efficiency rate.

Figure 3 shows that weaving plant 2 has a higher EER value of $56 \%$. This shows that the Weaving Factory 2 is more feasible to run in terms of the environmental impact caused and the benefits obtained. While the Weaving Factory 5 and Weaving Factory 8 had a lower EER value of $15 \%$ and $5 \%$. This is because the Weaving Factory 5 sells its products 
at a fairly cheap price. The Weaving Factory 8 sells this product at a higher price compared with Weaving Factory 5, while the price of the colouring material is more expensive. Thus the profit from the Weaving Factory 8 becomes less and does not cover the eco-cost value generated. The price of more expensive cotton yarn is also taken into consideration by the factory, so that most of the weaving factories still choose to do the dyeing process to dye the yarn.

Table 8. Eco-Costs per value ratio.

\begin{tabular}{|c|c|c|c|c|}
\hline \multirow{2}{*}{ Remarks } & \multicolumn{4}{|c|}{ EVR } \\
\cline { 2 - 5 } & PT 1 & PT 2 & PT 5 & PT 8 \\
\hline $\begin{array}{c}\text { Product Net Value } \\
\text { / 1 bal Ulos }\end{array}$ & $\mathrm{Rp} 12.945 .135$ & $\mathrm{Rp} 15.009 .172$ & $\mathrm{Rp} 6.936 .247$ & $\mathrm{Rp} \mathrm{4.809.568}$ \\
\hline Eco Cost & $\mathrm{Rp} 7.631 .650$ & $\mathrm{Rp} 6.590 .161$ & $\mathrm{Rp} \mathrm{5.879.357}$ & $\mathrm{Rp} 4.571 .261$ \\
\hline EVR & 0,6 & 0,4 & 0,8 & 0,9 \\
\hline
\end{tabular}

\section{Conclusions}

Based on the final results of the four weaving factories, the entire weaving factory has an EEI value between 0-1. It can be concluded that SMIs weaving ulos in Toba Samosir are financially affordable but not friendly to the environment (unsustainable). The ecoefficiency level of Weaving Factory 1, Weaving Factory 2, Weaving Factory 5, and Weaving Factory 8 is $41 \%, 56 \%, 15 \%$ and $5 \%$, respectively.

The recommendation of this research is to replace firewood into more environmentally friendly, Liquid Petroleum Gas (LPG). To improve the quality of the ulos weaving production process with machine looms, it is also very important to treat the wastewater. The simple liquid waste treatment for reducing COD levels is by the coagulationflocculation process. This process is relatively easy to implement and economically.

\section{References}

1. D.P. Sari, S. Hartini, D. I. Rinawati, T. S. Wicaksono, Pengukuran Tingkat Ekoefisiensi Menggunakan Life Cycle Assessment untuk Menciptakan Sustainable Production di Industri Kecil Menengah Batik. Jurnal Teknik Industri, pp. 137-144. (2012)

2. WBCSD, Eco-efficiency Learning Module. s.l.:World Business Council for Sustainable Development (2005)

3. J. B. Guinee, Handbook on Life Cycle Assessment. The Netherlands: Kluwer Academic Publishers (2002)

4. Vogtlander, LCA-based Assessment of Sustainability: The Eco-costs/Value Ratio (EVR). Delft University of Technology, Nederland (2010)

5. Tak Hur, T. L. Song, J. L. Hye, A Study on The Eco-efficiencies for Recycling Methods of Plastics Wastes, Departement of Material Chemistry and Engineering Konkuk University, Seoul Korea (2003)

6. Vogtlander, The Virtual Eco-costs ' 99 a Single based Indicator for Sustainability and the Eco-costs-value ratio (EVR) Model for Economic Allocation, International Journal of Life Cycle Assessment, 6(3), pp. 157-166. (2002) 